\title{
Multinational Corporations And Economic/Digital Technological Divide: An Analytical Approach To Global Economic Integration
}

Arav Ouandlous, (E-mail: ouandlou@savstate.edu), Savannah State University, USA Anthony Narsing, (E-mail: narsinga@savstate.edu), Savannah State University, USA

\begin{abstract}
Globalization is becoming a dominant characteristic of the world economy. It is exerting its sway over world markets; it's asymmetrical effect on developed and developing economies is becoming more visible, particularly in recent years. The multinational corporations (MNCs), which are driving and leading this globalization process, are generating again controversies with respect to their role in developing economies. A digital and economic divide is being created between the haves and the haves-not. Did the multinational corporations contribute to reduce or increase this gap? An analytical model is developed in this paper to understand and examine the impact of inward direct investment on developing countries.
\end{abstract}

\section{Introduction}

Globalization is becoming a dominant characteristic of the world economy. It is already exerting its sway over world markets. The modern multinational corporation seems to drive and lead this globalization process. Domestic and traditional markets seem too narrow for this multinational corporation (MNCS) to satisfy its everexpanding gargantuan appetite. New and fresh markets are always needed to sustain its rapid growth and profitability.

The sustainability of this corporate growth needs a domestic government support, ever declining trade barriers, free flow of capital, a viable and favorable legal, economic, financial and technological environment, and host governments friendlier to market driven economies. The leaders of the modern corporations are competitively positioning themselves on the highest mountain top to get a clear view on their future expansion and to carve out their potential world market domination. To do so they need to bend and/or transcend the economic, legal, and political traditional structures. In the new paradigm, they view themselves as the ultimate agent of change and the ultimate driver of the global economy. They believe that government policy should be viewed as a means for achieving their ultimate pursuit.

In return for their relentless pursuit for profits, the corporate leaders promise to make significant investments in host countries that would result in dissemination of technology and job-creation, outcomes that are widely believed to lead to the improvement of the overall economic and social conditions of the host countries. However, the pursuit of this endless corporate growth is not without cost; it has produced asymmetrical economic and technological effects not only between developed and developing economies but also between developing and the least developing economies.

Since growth depends largely on technology and technology depends mostly on foreign direct investments, which in turn depends on multinational and transnational corporations, it is natural to examine in section 2 of this paper the digital and technological divide between developed and developing economies and the asymmetrical 
impact of foreign direct investment on the developing and the least developing economies. In the third section, we will examine the literature on globalization and FDI and in the fourth section we will discuss our model on global integration of these countries and the requirements they must meet before accessing technology and/ or before engaging in the growth process and become a significant part of the world economy. In the fifth section, we end with a conclusion.

\section{Digital Divide.}

Internet usages, e-commerce, business-to-business (B2B) as well as business-to-consumer (B2C) data for the year 2000 illustrate the digital divide between the Haves and the Haves-not. For instance, out of 407.1 million people who have access to the Internet, $41 \%$ are located in North America, 27.8\% in Europe, 26\% in Asia Pacific, 4\% in Latin America, $0.8 \%$ in Africa and $0.6 \%$ in the Middle East. North America and Western Europe make up the largest share (68.8\%), Asia Pacific 26\% and the remaining developing countries 5.4\% (Latin America, 4\%; Africa, 0.8\%; Middle East, 0.6\%) (Economists 07/2000); while 35 billion e-mail messages per day were projected by 2005 (ITA/10-00); and over 1 billion Mobile phone subscriptions worldwide are expected by next year, (Economist, 7/2000), developing economies will share the least in the race for digital technology, as the table below indicates.

Table 1. Digital Divide - International Trends.

\begin{tabular}{|l|c|c|}
\hline Region & \multicolumn{2}{|c|}{ Internet users as \% of population } \\
\hline & $\mathbf{1 9 9 8}$ & $\mathbf{2 0 0 0}$ \\
\hline Latin America and the Caribbean & 0.8 & 3.2 \\
\hline East Asia and the Pacific & 0.5 & 2.3 \\
\hline South Asia & 0.04 & 0.4 \\
\hline World & 2.4 & 6.7 \\
\hline USA & 26.3 & 54.3 \\
\hline
\end{tabular}

Source: UNDP 2001: Human Development Report

Even though the Internet usage as a percentage of the population has almost tripled worldwide between 1998 and 2000 as shown in Table 1, the U.S. has by far the largest percentage Internet usage in the world (54.3\%) compared to less than $6 \%$ for all developing countries, including Latin America and the Caribbean, East Asia and the Pacific and South Asia in 2000.

As Table 2 below indicates, less than 40 personal computers per 1,000 people between 1997-2000 were available for most of the developing economies versus 287 for the new industrialized ones, and 375 for the industrial countries. When it comes to the Internet host sites, the former countries have 13 sites compared to $1,113.6$ for the industrial countries. The new industrialized economies are catching up with the industrialized countries in matter of personal computer and Internet usage. The great digital divide is not between newly industrialized economies and the advanced industrialized ones, but between the latter and the rest of the developing economies. Despite a significant growth in the Internet usage, developing economies are still lagging far behind the advanced industrialized nations in the use of technology, particularly the digital technology, as indicated by the data below.

Table 2: Selected IT Indicators.

\begin{tabular}{|l|c|c|c|}
\hline & Personal Computers & \multicolumn{2}{|c|}{ Per 10,000 people } \\
\cline { 3 - 4 } & $\begin{array}{c}\text { Per 1,000 people } \\
\mathbf{1 9 9 7 - 2 0 0 0}\end{array}$ & $\begin{array}{c}\text { Internet Hosts } \\
\mathbf{1 9 9 8 - 2 0 0 0}\end{array}$ & $\begin{array}{c}\text { Internet Users } \\
\mathbf{1 9 9 8}-2000\end{array}$ \\
\hline Newly Industrialized Economics & 287 & 190.6 & 1,820 \\
\hline People's Republic of China & 11 & 0.4 & 88 \\
\hline Southeast Asia & 25 & 7.2 & 227 \\
\hline South Asia & 3 & 0.2 & 11 \\
\hline Central Asian Republicans & n.a. & 4.6 & 3 \\
\hline The Pacific & n.a. & 0.6 & 2,578 \\
\hline Industrial Countries & 375 & $1,113.6$ & 3 \\
\hline
\end{tabular}

Source: World Bank, World Development Report and World Development Indicators database (2002). 
Business to business (B2B) revenues are projected to reach $\$$ U.S 6.3 trillion by 2004 while business to consumer (B2C) revenues are projected to reach \$U.S 454 billion during the same period. (Forrester, 10/00). Ecommerce predictions are projected to reach \$U.S 7.8 trillion by 2004. Twelve countries account for nearly $85 \%$ of worldwide net sales: United States (\$U.S 3.2 trillion), Asia Pacific (\$U.S 1.6 trillion), Western Europe (\$U.S 1.5 trillion), Latin America (\$U.S 82 billion); and Eastern Europe, Africa and the Middle East altogether account for \$U.S 68.6 billion. (Forrester, 10/00).

The above data show clearly the technological digital divide between the advanced industrialized countries and the less advanced ones. Many of the developing economies lack the financial, economic, political, institutional, and technological support to keep pace with the advanced industrialized nations. Since technology is believed to be the engine of economical growth, is the globalization helping or hindering its dissemination in developing countries? Since growth requires technology and technology requires FDI, it is necessary to examine the role and conditions of the MNCS in releasing this technology in the developing economies. The literature on the role of MNCS in developing economies is vast, controversial and in some areas inconclusive: there are as many studies showing the benefits of FDI as those showing its disadvantages. Let's take a synopsis view of this literature.

The multinational corporations are driving the globalization process. The largest and the most powerful belong to the most advanced industrialized nations. As the table below indicates, among the world's 45 nonfinancial multinational corporations in 2000, (22\%) were from the United States, $16 \%$ were from Japan, $13 \%$ were from France, $11 \%$ were from the United Kingdom, 9\% were from Germany; the rest was shared by Netherlands, Switzerland and Sweden (3\% each); Canada, Spain and Italy (2\% each); Hong Kong, Mexico, Norway, Australia, Venezuela, Malaysia, Finland and Belgium, United Kingdom/Netherlands, United Kingdom/Australia and Germany/United States (1\% each).

Table 3: The World's 45 non-financial, ranked by foreign assets, 2000.

\begin{tabular}{|c|c|c|c|c|c|}
\hline & \multicolumn{5}{|c|}{ Number of Industries in Each Country } \\
\hline Countries & $\begin{array}{l}\text { Food and } \\
\text { Beverage }\end{array}$ & Motor Vehicles & $\begin{array}{c}\text { Electric and } \\
\text { Electronic } \\
\text { Equipment } \\
\text { Component }\end{array}$ & Telecom & Petroleum \\
\hline U.S. & & 3 & 3 & 2 & 3 \\
\hline Japan & & 4 & & & \\
\hline France & 1 & 2 & 5 & & 1 \\
\hline U.K. & 1 & & & 2 & 2 \\
\hline Germany & & 2 & 1 & & \\
\hline South Korea & & & 1 & & \\
\hline Spain & & & & 1 & 1 \\
\hline Malaysia & & & & & 1 \\
\hline Italy & & 1 & & & 1 \\
\hline Belgium & 1 & & & & \\
\hline Netherlands & & & 1 & & 1 \\
\hline Sweden & & & 1 & 1 & \\
\hline Switzerland & 1 & & & & \\
\hline Venezuela & & & & & 1 \\
\hline
\end{tabular}

Source: Constructed from the UNCTAD database

These numbers clearly reflect the supremacy of the U.S. and the dominance of Japanese, French, German and British MNCs. For instance, MNCs from Japan (4), United States (3) and Germans (3) dominate the Motor Vehicle industries; they are followed by French (2) and Italians (1); the Electric and Electronic Component Industry is dominated by Japan (5), the United States (3), Netherlands, Germany, Swedish and South Korean (1) MNCs; while the United States (2), Britain (2), Swedish (1) and Spanish (1) MNCs dominate the Telecommunication industry; the United States (3), Britain (2), Netherlands (1), French (1), Spanish (1), Italians (1), Venezuelans (1) and Malaysians (1) dominate the Petroleum Industry. 
Table 3 brings about also new players in the global economic reach. These players are not as one would expect from advanced industrialized nations but from the less advanced nations such as Mexico, Malaysia, Republic of Korea, and Venezuela. The fact that these countries made it to the top 100 non-financial corporations signals a new economic era and reflects the drive and readiness of these countries to enter the race for global markets. More developing countries, though, are emerging as global players, as the table below indicates.

Table 4 indicates that there are more developing countries entering the global foreign direct investment race.

Table 4:The Top 50 Transnational Corporations From Developing Economics, Ranked By Foreign Assets, 2000.

\begin{tabular}{|c|c|c|c|c|c|c|c|c|c|c|c|}
\hline \multirow[b]{2}{*}{ Countries } & \multicolumn{11}{|c|}{ Number Of Industries In Each Country } \\
\hline & $\begin{array}{l}\text { Divers- } \\
\text { ified }\end{array}$ & $\begin{array}{l}\text { Elec/ } \\
\text { Gas } \\
\text { Water }\end{array}$ & $\begin{array}{l}\text { Bus. } \\
\text { Srv }\end{array}$ & $\begin{array}{l}\text { Metal/ } \\
\text { Metal } \\
\text { Prod. }\end{array}$ & Const. & $\begin{array}{l}\text { Transp } \\
\& \\
\text { Stor'ge }\end{array}$ & $\begin{array}{l}\text { Non- } \\
\text { Metallic }\end{array}$ & $\begin{array}{l}\text { Food } \\
\text { and } \\
\text { Bev. }\end{array}$ & $\begin{array}{l}\text { Electric \& } \\
\text { Electronic } \\
\text { Equip't } \\
\text { Comp't }\end{array}$ & $\begin{array}{l}\text { Pet. } \\
\text { Expl } \\
\text { /ref./ } \\
\text { dist } \\
\end{array}$ & Other* \\
\hline $\begin{array}{l}\text { Hong Kong, } \\
\text { China }\end{array}$ & 4 & 2 & 2 & 1 & 1 & 1 & & & 1 & & \\
\hline Mexico & 2 & & & & & & 2 & 2 & & & \\
\hline $\begin{array}{l}\text { Korea, } \\
\text { Republic of }\end{array}$ & & & & 1 & & & & & 3 & & 1 \\
\hline Venezuela & & & & & & & & & & 1 & \\
\hline Malaysia & 3 & & & & 1 & & & & & 1 & \\
\hline Singapore & 1 & & & & & 2 & & 1 & 1 & & 1 \\
\hline Brazil & & & & 1 & & 1 & & & & 1 & 1 \\
\hline South Africa & 1 & & & & & & & 1 & & & 1 \\
\hline China & & & & 1 & & & & 1 & & & 1 \\
\hline Philippines & & & & & & & & 1 & & & \\
\hline Argentina & & & & & & & & & & 1 & \\
\hline Taiwan & & & & & & & & & 2 & & \\
\hline Saudi Arabia & & & & & & & & & & 1 & \\
\hline Chile & & & & & & & & & & 1 & \\
\hline
\end{tabular}

Source: Table constructed from UNCTAD/ Erasmus University database

*other category includes: retail industry for S. Africa; Chemical industry for China; paper industry for S. Africa; mining/ quarrying for Brazil; motor vehicle for S. Korea; and telecom for Singapore

Hong Kong (12), Singapore (6), Mexico (6), Malaysia (5), Korea (4) and Brazil (4), as shown in Table 4, are countries that have the largest multinational corporations among developing economies, with a major noticeable lead by Hong Kong, with twelve corporations. They are followed by countries such as South Africa (3); China (3), Taiwan (2); Saudi Arabia (1); Chile (1); Argentina (1); Philippines (1). South Africa, Taiwan, and particularly China, are increasingly becoming candidates in the race for the global economic reach.

One cannot fail to notice new comers in the global arena, Saudi Arabia, which made it for the first time in the top 50 TNCs from developing economies, and Argentina and Chile. Although the multinational corporations from these countries are relatively small in numbers and influence, they are, nevertheless, emerging as new competitors in the global market place.

There are countries that have benefited significantly from globalization and inward foreign direct investment, such as the developed countries aforementioned and the newly industrialized ones. There are others who have not benefited from the globalization, such as the least developing economies, particularly the Sub-Sahara region, which has seen the number of people living below the poverty line increased between 1987 and 1999. 
Table 5: Regional Breakdown of Poverty in Developing Countries.

\begin{tabular}{|l|r|r|r|}
\hline & \multicolumn{3}{|c|}{$\begin{array}{c}\text { Number Of People Living On Less } \\
\text { Than } \mathbf{\$ 1} \text { Per Day (Millions) }\end{array}$} \\
\hline Region & $\mathbf{1 9 8 7}$ & $\mathbf{1 9 9 0}$ & $\mathbf{1 9 9 9}$ \\
\hline East Asia and Pacific & 418 & 486 & 279 \\
\hline$\quad$ Excluding China & 114 & 110 & 57 \\
\hline Europe and Central Asia & 1 & 6 & 24 \\
\hline $\begin{array}{l}\text { Latin American and the } \\
\text { Caribbean }\end{array}$ & 64 & 48 & 57 \\
\hline Middle East and North Africa & 9 & 5 & 6 \\
\hline South Asia & 474 & 506 & 488 \\
\hline Sub-Saharan & 217 & 241 & 315 \\
\hline Total & 1,183 & 1,292 & 1,169 \\
\hline Excluding China & 880 & 917 & 945 \\
\hline
\end{tabular}

Source: Adapted from the World Bank Staff Estimates, GEP 2003

According to the World Bank studies, poverty in relative terms in the World has been declining over the past few decades while absolute poverty has been on the increase in some regions as the tables below indicate.

Figure 1: Global Poverty Rates: Percent of People Living on Less than \$1 per day

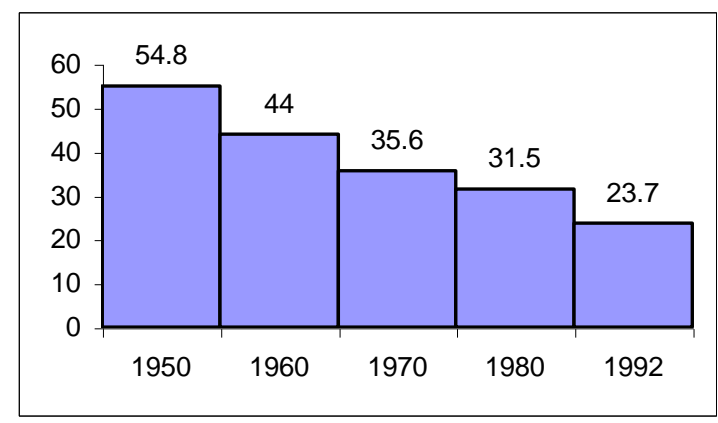

Source: Bourguignon and Morrisson (2002);

Taken From Stanley Fisher in Globalization and its Challenges.

According to Table 5 above, there are more than 1 billion people living on less than \$1 per day in 1999. The decrease in the number of people living on less than \$1 per day in the world between 1987 and 1999 has been very negligible: it amounted to 14 million people. In some regions, the number of people living below the poverty line has, on the contrary, increased instead of decreasing. These numbers can be interpreted that globalization has not benefited everyone; and it has not reduced significantly the number of people living below the poverty line.

The breakdown by region shows clearly that Sub-Sahara region is the region that suffers the most from poverty. The number of people living below the poverty line in this region has increased by 98 million between 1987 and 1999; Europe and Central Asia is another region that has seen the number of people living below the poverty line increased by 23 million over the same period.

When it comes to the literature on poverty and global inequality one finds conflicting results with respect to the measurement of global inequality. For instance, Milanovic (1999) has found increase in global inequality between 1988 and 1993 while Sala-I-Martin (2002) finds large increase in global inequality between 1980 and 1998.

The empirical evidence on the effect of foreign direct investment on host economies growth is mixed. Some countries have benefited greatly from FDI and some did not. For instance, United States, Australia, Canada 
and other countries of Western Europe who have been the largest recipient of FDI have, as the evidence of their success shows, benefited vastly from it. Countries such as Korea, Singapore, Taiwan and Hong Kong are another example of countries that benefited from FDI. Emerging countries such as Mexico, Malaysia, South Africa, Turkey and countries of Eastern Europe, and recently China, are additional testimonies of the positive impact of FDI on economic development. According to Sun (2002), FDI played a major role in the present China's development: "Among the factors promoting export growth, DFI has played an important role, with foreign-invested enterprises (FIEs) being the most active players in the export expansion drive. During the period 1981 to 1995, exports by FIEs grew at an annual rate of $63.3 \%$, with the value of exports increasing from US $\$ 32$ million to US $\$ 468,80$ million. Consequently, the share of FIEs in the total exports of China increased from $0.1 \%$ in 1981 to $31.5 \%$ in 1995 ." From a historical economical development perspective one can observe that there is no country in the world that reached significant economic success without receiving massive FDI. One can also observe that many countries in Latin American, African and Middle East, which received a significant amount of inward direct investments, were not able to reach a significant economic progress.

If inward direct investments are having a negative impact on economic growth or development, as believed by some, developed countries will be the ones that will be affected the most. They saw their inward direct investments, as the table below indicates, increase by $82.4 \%$ between $1986-1990,61.2 \%$ between 1993-1998 and $80.0 \%$ between 1999 and 2000. The table below rather suggests that countries that have received the most inward direct investments are the countries that developed the most, such as developed and new industrialized countries; the countries that received the least are the ones that developed the least, such as some developing countries, particularly the least developed countries that saw a very negligible growth in their inward direct investments over the period considered. Japan is an exception in this regard. The country developed itself without much significant growth in its inward direct investments.

The third column of table 7 below indicates that developed countries have seen, from 1993-1998 to 199920001, a substantial increase (from $61.2 \%$ to $80 \%$ ) in their overall inward FDI inflows; while developing countries have seen a significant drop (from $35.3 \%$ to $17.9 \%$ ) during the same period.

Table 7: Distribution of World FDI Inflows, 1986-2001 (\%).

\begin{tabular}{|l|r|r|r|}
\hline Region & $\mathbf{1 9 8 6 - 1 9 9 0}$ & $\mathbf{1 9 9 3 - 1 9 9 8}$ & $\mathbf{1 9 9 9 - 2 0 0 0}$ \\
\hline Developed Countries & 82.4 & 61.2 & 80.0 \\
\hline Western Europe & 38.4 & 33.7 & 51.9 \\
\hline European Union & 36.2 & 32.1 & 50.2 \\
\hline Japan & 0.2 & 0.3 & 0.8 \\
\hline United States & 34.6 & 21.7 & 22.6 \\
\hline Developing Countries & 17.5 & 35.3 & 17.9 \\
\hline Africa & 1.8 & 1.8 & 0.8 \\
\hline $\begin{array}{l}\text { Latin America and the } \\
\text { Caribbean }\end{array}$ & 5.0 & 12.3 & 7.9 \\
\hline \multicolumn{1}{|c|}{ Asia and the Pacific } & 10.6 & 21.2 & 9.2 \\
\hline $\begin{array}{l}\text { Central and Eastern } \\
\text { Europe }\end{array}$ & 0.1 & 3.5 & 2.0 \\
\hline $\begin{array}{l}\text { Least Developed } \\
\text { Countries }\end{array}$ & 0.4 & 0.6 & 0.4 \\
\hline
\end{tabular}

Source: UNCTAD, FDI/TNC database

As a result of the global economic slow down, foreign direct investment flows have significantly declined over the past two years, and this for the first time since the early 1990s; a period in which they experienced the largest drop since the past three decades. FDI inflows which amounted to \$US735B dropped to 51\% while FDI outflows which amounted to \$US621B dropped by 55\%.

This decline in FDI affected differently both developed and developing economies. Developed economies saw their FDI inflows dropped by almost 50\% (from \$US1 Trillion to \$US503B in 2001); while developing economies by almost 14\% (from \$US238Bto \$US205B) for the same period, (UNCTAD REPORT). 
When one examines the record of employment of foreign affiliates' in host countries one will observe an increase not a decrease in employment from 17,987,000 million in 1982 to 53,581,000 million in 2001, an overall increase of almost $198 \%$. Needless to say, 54 million created jobs will not solve the unemployment problem of the developing countries, since most of these jobs are created in developed and emerging developing countries- not in the least developed countries, which need more economic help.

How does one explain the asymmetrical effect of foreign direct investment on developed and developing countries? To do so, we will examine the evidence suggested by the literature in the section below and then discuss our model of global integration in the following section.

\section{Literature Review}

The studies on the benefits and disadvantages of multinationals corporations to host countries are abundant. The benefits of foreign direct investments are shown in Hirschman (1958), Weisskoff and Wolff (1977), Lall (1978), Helpman and Krugman (1985) and Ramsletter (1991). The benefits of FDI in the context of backward and forward linkages are explored by Andres Rodriguez-Clare (1996, p.852); The author has shown that "the linkage effect of multinationals on the host country is more likely to be favorable when the good that multinationals produce uses intermediate goods intensively, when there are large costs of communication between the headquarters and the production plant, and when the home and host countries are not too different in terms of the variety of intermediate goods produced. If these conditions are reversed, then multinationals could even hurt the developing economy, formalizing the idea that multinationals may create enclave economies within developing countries."

On the other hand, we find several studies that criticize the role of FDI in developed as well as in developing countries, including radical political economists, government officials, politicians and political activists as well as some mainstream academicians. For instance, the French President Charles de Gaulle and author, JeanJacques Servan-Schreiber, in his book, the American Challenge, were among the prominent French critics of the American foreign investment. The radical view on FDI argues that since the MNC is an instrument of imperialist domination, FDI should be looked upon with suspicious eyes. This view takes its roots in the Marxian view of the world, and Sweezy and Magdoff (1972) Hood and Young (1972), Frieger (1997), Barnes (1999), Amin (1997), Weiss (1998), Korten (1995) and Alexander (1996) are among the prominent ones. Most of the radical studies contain some economic and mostly non-economic factors. They generally support the view of the ill effects of multinational corporations on host developing countries.

Several studies also have attempted to show direction of causality or relationship between FDI and economic growth, between changes in income and changes in inequality, between openness and economic growth, between capital flows and development, between property rights and economic growth, and between inflation and economic growth. However, there is no overwhelming consensus on the results of these studies.

For instance, authors such as Deininger and Squire (1996), Chen and Ravallion (1997), Easterly and David Dollar and Kray (2002) found no supporting evidence for the existence of a relationship between changes in income and changes in inequality. Other studies Fischer (1993), Easterly and Rebello (1993) found that inflation and government consumption are not respectively conducive to growth; on the other hand studies that examined imports and exports as they are related to GDP were found to stimulate economic growth, Frankel and Romer (1999), and financial developments, Levine, Loayza, and Beck (2000).

There is a consensus on the evidence suggested by the literature on trade and growth. Numerous studies such as Dollar (1992), Ben-David (1993), Sachs and Warner (1995), Edwards (1998), Romel (1999), Dollar and Kraay (2001a, 2001b), just to cite the prominent ones in the field, show the evidence for the existence of a positive relationship between openness to trade and economic growth. However, Birdsall (2002) finds that openness to trade has not resulted in systematic growth for the least developed countries. Also, the literature on international finance and development does not support the evidence of a stronger link between capital accounts and economic growth Fischer (2003). 
David Dollar and Art Kray (2002, p32) have shown that growth driven by openness and the micro policies benefits the poor, and the growth of income for the poor is not systematically related to pro-poor policies. Last but no least, property rights have been found to play an important role in the framework of economic growth, Knack and Keefer (1995). Gordon (2001) cited a considerable body of literature that shows that foreign owned firms in Canada are more productive than Canadian owned firms and the main reason for this is the superior technology of U.S. owned firms operating in Canada, result that would encourage more calls for foreign direct investment to improving productivity. How does one reconcile these divergent views? The model below attempts to do so.

\section{Model And Analytical Interpretation}

We propose a quantitative model that captures the influence of economic variables on inward investments and an analytical interpretation to bridge between the latter and the non-economic variables.

The formal model that will capture the relationships between inward investments and economic and noneconomic variables of host countries can be stated as follows:

$$
\mathrm{Y}=\alpha+\beta_{1} \mathrm{X}_{1}+\beta_{2} \mathrm{X}_{2}+\beta_{3} \mathrm{X}_{3}+\beta_{4} \mathrm{X}_{4}+\beta_{5} \mathrm{X}_{5}
$$

where $\mathrm{Y}$ expresses the relative level of inward investments; $\alpha$, the autonomous level of investment or foreign aid; $\mathrm{X}_{1}$, Gross Domestic Product (GDP); $\mathrm{X}_{2}$, openness of the economy, expressed as the sum of imports and exports over GDP; $\mathrm{X}_{3}$, government share in the GDP; $\mathrm{X}_{4}$, number of BITS in favor of the MNCS; and $\mathrm{X}_{5}$, a dummy variable that captures the remaining non-economic factors such as political social and institutional.

$\mathrm{X}_{1}$ and $\mathrm{X}_{2}$ are expected to be positively related to inward investments; while $\mathrm{X}_{3}$ is a country case driven; it can be positive in the case of countries, such as China, which has seen a significant increase it its inward investments, despite its larger role in the economy, as measured by $\beta_{4}$; it can be negatively related in other cases of more controlled economies. This variable will serve to track the importance of or the limited role of the government in the economy. This model will capture most quantifiable economic variable that will promote or inhibit inward investments. The lack of data, particularly for the least developed economies, is limiting the empirical application of our model; we are also aware of its limit in explaining the influence of non-economic factors on inward investments. Because of these complexities, an analytical interpretation of them is more than warranted.

The release of technology by MNCs is based on the firm's structure and profit maximization model. MNCs are not goodwill providers. They are profit seekers. We assume they are driven by market share and profit maximization objective - not by non-economic factors. When the latter factors are present in their profit pursuit, they are at best incidental to their maximization profit objective. We also assume that the first mover's advantage and market structure are important in the dictation, bargaining and release of the technology between MNCs and developing countries. The mission of the MNCs is neither to promote economic growth nor to promote the welfare of the host countries, but to pursue their economic objectives. The role of promoting growth and economic development rests on the host governments not on the MNCs.

The MNCs will seek countries or regions that are more lucrative and of strategic importance to them. It behooves the host governments to figure out which role and which position MNCs will fit in their development agenda. The MNCs will exploit the non-economic factors loopholes to enhance their profitability, their market domination, and their strategic positioning. Following these assumptions, our model predicts that MNCs will invest in countries in which they will find economic, social, and political conditions favorable and compatible to their maximization profit objective and their strategic marketing positioning.

Because of similarities in economic and political systems, advanced industrialized nations exhibited an extraordinary growth in inward investments during 1986 - 2000 period. The developed economies, as suggested by Table 7, have averaged approximately 74.5\% growth of inward investment between 1986 and 2000 versus an average growth of $23.6 \%$ for developing countries, for similar investments and over the same period. A further breakdown of the latter reveals, for the same period, that Africa has registered one of the lowest average growth of 
inward investments (one percent and half) in the world. The least developed countries scored for the similar period and for similar investment inflows, the lowest average growth (less than half percent) of all. Africa and the rest of the least developed countries have the least similarities in economic social, legal and political systems than those of the developed economies, which are the homes of the largest and most powerful multinational corporations. On the other hand, the newly industrialized countries such as South Korea, Taiwan, Singapore, and Hong Kong, which exhibit political systems that are friendlier and supportive of market driven economies have seen significant growth in their inward investments. Asia and South Pacific countries have averaged 13.7\% growth in inward investments for the 1986 - 2000 period, compared to Central and Eastern Europe that whose political and economic systems are highly differentiated from those developed economies.

Countries that do not have economic bargaining power are finding themselves cornered to adopt policies that promote liberalization policies and make changes in FDI laws and regulations that are favorable to MNCs, as shown clearly in the figure and table below.

Figure 1: Types of Changes in FDI Laws and Regulations, 2001

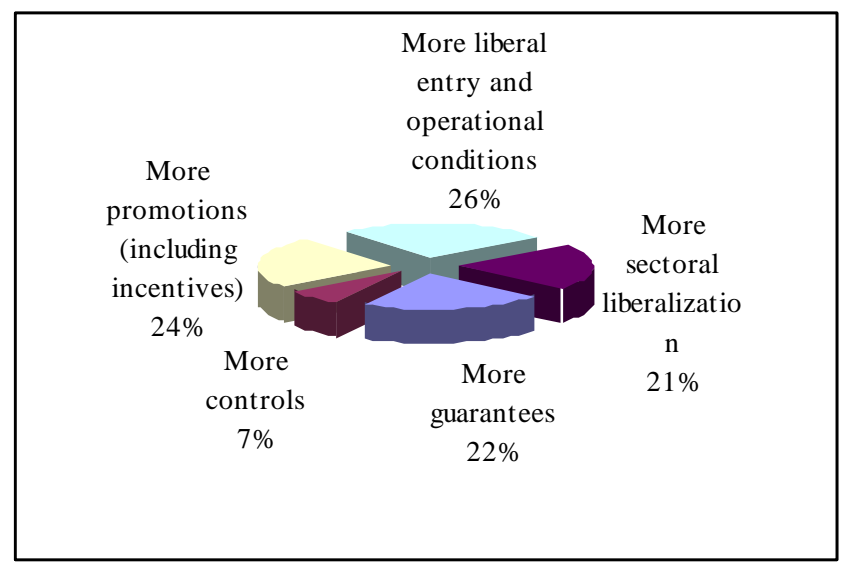

Source: UNCTAD

Table 9: National Regulatory Changes, 1991-2001

\begin{tabular}{|c|c|c|c|c|c|c|c|c|c|c|c|}
\hline Item & 1991 & 1992 & 1993 & 1994 & 1995 & 1996 & 1997 & 1998 & 1999 & 2000 & 2001 \\
\hline $\begin{array}{l}\text { Number of countries that } \\
\text { introduced changes in } \\
\text { their investment regimes }\end{array}$ & 35 & 43 & 57 & 49 & 64 & 65 & 76 & 60 & 63 & 96 & 71 \\
\hline $\begin{array}{l}\text { Number of regulatory } \\
\text { changes of which }\end{array}$ & 82 & 79 & 102 & 110 & 112 & 114 & 151 & 145 & 140 & 150 & 208 \\
\hline -More favorable to FDI & 80 & 79 & 101 & 108 & 106 & 98 & 135 & 136 & 131 & 147 & 194 \\
\hline -Less favorable to FDI & 2 & - & 1 & 2 & 6 & 16 & 16 & 9 & 9 & 3 & 14 \\
\hline
\end{tabular}

Source: UNCTAD, World Investment Report 2002

The number of countries that introduced changes in their investment regimes has, as the table above indicates, more than doubled between 1991 and 2001. The number of regulatory changes that were favorable to foreign direct investment has increased by more than $150 \%$ during the same period, which indicate the bargaining power of MNCs and the pressure the latter exert on host developing countries, particularly on the least developed countries. The bottom 20 poorest countries, which make an average of $\$ 222$ per capita, have the least bargaining power when compared to the top 20 countries that make an average a slightly higher than $\$ 25,125$ per capita. (World Development Report; 1999/2000). 


\section{Conclusions}

Developing economies need technology to promote their development. The least developed ones need it to break out of their vicious development circle. The multinational corporations will not release this technology unless these countries make changes to accommodate their corporate strategy and to meet their shareholders/maximization/profit criteria. Countries, which are willing to meet the latter criteria, as exemplified by the newly industrialized countries and the emerging developing economies, including China, to name just few, are benefiting from inward investments. Countries that are resisting inward investments or are reluctant to embark on it, are receiving the least benefits from it. And the least developed countries have the least bargaining power toward the MNCs.

The data examined in this paper suggest that inward direct investments are not hindering economic growth; on the contrary. What developing countries need are more - not less inward direct investments. It is the host government's policy toward the nature and distributional effects of inward investments that will determine the benefits or the ill effect of these investments. Inward investments that create backward and forward linkages were shown to generate more growth than investments that exhibit the weakest economic linkages.

The evidence presented so far leads us to believe that MNCs are not only moving toward globalization of markets and globalization of production, but toward a unified global market economic system. And the only potential bargaining power left to developing countries is to form an alliance among them to protect their interest against the most powerful multinational corporations. This potential alliance can not survive for too long given the fragmentation and the divergence of interests that exist among these countries; The emergence and increasing number of multinational corporations from developing countries, as shown in this paper, are making this alliance even more fragile. An investigation into the effect of non-economic factors on inward direct investment and growth can be a worthy pursuit for future research.

\section{References}

1. $\quad$ Alexander, T (1996) Unraveling Global Apartheid (Oxford; Polity Press)

2. Amin, S (1997) Capitalism in the Age of Globalization (London; Zed Books)

3. $\quad$ Barnes, J (1999) Capitalism's World Disorder (New York; Pathfinder)

4. Birdsall, N., "A Stormy Day on an Open Field: Asymmetry and Convergence in the Global Economy", in David Gruen, Terry O’Brian and Jeremy Lawson, eds, Globalization, Living Standards and Inequality, Reserve Bank of Australia and Australian Treasury.

5. Chen, S. and Ravallion, M., "How did the World's Poorest Fare in the 1990s", Review of Income and Wealth, 40 (4), pp. 359-376.

6. Dollar, D. and Kray, A., Growth is Good for the Poor, Washington, DC, World Bank, (2001a).

7. Dollar, D. and Kray, A., Institutions, Trade, and Growth, Washington, DC, World Bank, (2002).

8. Dollar, D. and Kray, A., Trade, Growth and Poverty, Washington, DC, World Bank, (2001b).

9. Dollar, D., "Outward-Oriented Developing Economies Really Do Grow More Rapidly: Evidence from 95 LDCs", 1976-85 Economic Development and Cultural Change, 40, (April), 523-544.

10. Easterly, W. and Levine, R., Tropics, Germs, and Crops: How Endowments Influence Economic Development", NBER Working Paper w9106.

11. Edwards, S., "Openness, Trade Liberalization and Growth in Developing Countries", Journal of Economic Literature, 31, 3 (Sept), 1358-1393.

12. Fischer, S., "Capital Account Liberalization and the Role of the IMF", Princeton Essays in International Finance (207): pp. 1-10, 1998.

13. Fischer, S., "The Role of Macroeconomic Factors in Growth", Journal of Monetary Economics, (December) 32 (3), pp. 485-512, (1993).

14. Forester Research Group (2000)

15. Francel, J. and Romer, D., "Does Trade Cause Growth?", The American Economic Review. (June) pp. 379-399, (1999). 
16. Frankel, J. and Romer, D., "Does Trade Cause Growth?", American Economic Review, 89, 3 (June), pp. 379-99.

17. $\quad$ Freider, W (1997) One World, Ready or Not (New York; Simon and Schuster).

18. Gordon, M., Multinatopnal Corporations, Productivity Growth and National Welfare in Host and Home Country: A Canada-U.S. Comparison, Working Paper, University of Toronto, (2001).

19. Helpman, Elhanan and Krugman, P., Market Structure and Foreign Trade; Cambridge, MA: MIT Press, 1985.

20. Hirchman, A., The Strategy of Economic Development. New Haven, CT: Yale University Press, 1958.

21. Knack, S. and Keefer, P., "Institutions and Economic Performance: Cross Country Tests Using Alternative Intuitional Measures", Economics and Politics, (November), 7(3), 207-227.

22. Korten, D C (1995) When Corporations Rule the World (San Francisco, LA, Bewett-Koehler)

23. Lall, S., Transnational, Domestic Enterprises and Industrial Structure In Host LDCs: A Survey, Oxford Economic Press, July 1978, 30(2), pp217.48.

24. P.M. Sweezy and H. Magdoff, The Dynamics of the U.S. Capitalism, New York: Monthly Review Press, (1972).

25. Ramsletter, E.D., Direct foreign investment in Asia'a developing economies and structural change in he Asia-Pacific region, New York: Westview Press, 1991.

26. Rodriguez-Clare, A., The Division of Labor, Agglomeration Economies and Economic Development, Ph.D dissertation, Stanford University, 1993.

27. S. Hood and S. Young, The Economics of the Multinational Enterprise, London: Longman, (1979).

28. Sachs, J. and Warner, A., "Economic Reform and the Process of Global Integration", Brookings Papers on Economic Activity, 1, pp. 1-118.

29. Sala-i-Martin, X., The Disturbing "Rise" of Global Income Inequality, NBER Working Paper w8904 (April).

30. Sun, H., Journal of Contemporary Asia; 1999, Vol. 29 Issue 3, p.362

31. UNCTAD, based on its FDI/TNC database and UNCTAD estimates selected indicators of FDI and International Production, 1982-2001

32. Weiss, L (1998) The Myth of the Powerless State (Oxford; Polity Press)

33. Weisskoff, R. and wolff, E., "Linkages and Leakages: Industrial Tracking in an Enclave Economy", Economic Development and Cultural Change, July 1977, 25(4), pp. 607-28.

Notes 
Notes 